\title{
The Importance And Place Of Illustrated Fairy Tale Books In Art Education For Pre-School Children
}

\author{
Sonnur ÖZDEMIR \\ Giresun University, Turkey \\ sonnurozdemir@gmail.com
}

\begin{abstract}
Illustrated fairy tale books targeted for preschoolers play an important role in children's linguistics, cognitive and interpersonal developmental phases. In other words, fairy tales that are designed and illustrated regarding a child's perception of reality contribute to their visual, linguistics, cognitive, intrapersonal and interpersonal growth in turn. As a result, child emulates the world designed in the fairy tales in accordance with their understanding of the world and would take their first steps in art education. illustrations done efficiently would act as stimulus that would trigger a child's hearing and visual senses along with their imagination.
\end{abstract}

Such illustrations depicted should either complement what it is told in the written text or hidden in between the lines. On the other hand, illustrated books which are prepared for children who are attending a preschool or who are in the early years of primary school education, that lack written textswould help children create their own stories. These books assist in developing symbols for concepts that would be kept in children's memories. Consequently, it advances sense perception of children.

A well-known art scholar, Victor Lowenfeld, developed a theory of stages in artistic development. They are listed as; Scribble (ages 2-4), Preschematic (ages 4-7), schematic (ages 7-9), Dawning Realism (ages 9-11), and Pseudorealism (ages 11-13).

Illustrated fairy tale books for preschoolers are important in terms of art classes. It is possible to give art education to children strating from the age of 2 in their natural environments with the help of appropriately illustrated fairy tale books.

Key Words: Pre-school, Illustrated fairy tale books, Arts education, Children's arts education, Story. 


\section{Introduction}

Starting right after 0-3 years old baby period finishes and covering the ages between 3 to 5 preschool education is considered as the first step in the child's formal education prior to the eight years of compulsory primary education. This period will provide a basis for preparing children to the compulsory primary education in terms of its contribution to children's psychological and social developments (Dursun, 2008).

Preschool period paves the way for human life. During that time, the child is eager to communicate with the environment, and through these interactions child is introduced to the value judgments of the society and as a result, defines the world around itself and gains habits in line with the culture and customs (Şahin, 2005; Akt: Güleç, H.Ç. 2008). The education process starts in the family, grows with the close environment and continues with business life. Behavior and skills gained shapes the child's life (Zembat and Unutkan, 2001).

According to Oğuzkan (1979), children's literature covers anything and everything that are targeted towards dreams, emotions and ideas of children in both spoken and written works. Similar to works prepared for adults, these literary pieces belonging to various genres needs to be influential. For that reason, in its most general form, children's literature can be defined as “eminent and effective works specifically written for children by skillful writers". Şirin (1994) defines the term children's literature as a support system that facilitates growth and development of dreams, emotion, ideas, sensitivity, likes and dislikes of a child while teaching and entertaining with a childlike style at the same time. By taking this definition as basis, it would not be wrong to interpret it at a wider scale. Children meeting books with artistic design in the preschool period can start with art education with the help of these books. 
In Sever's (2012:17) viewpoint, children's literature is the general name given to works targeted towards a life span starting with the early childhood and covering the teenage years. These works are in level with the child's language development and competence and includes lingual and visual prompts, which possess artistic quality.

Starting from the early days of its life, child interacts with the environment around. The main drive to do that is the desire to get to know people, life and the environment s/he lives in for children between the ages of 0 and 6 , supporting this desire to learn with the help of books with illustrations or pictures is seen as a sensible approach to help raise the quality of the next developmental stages of a child (Sever, 2008:3).

The span between the ages of 0 to 2 can be considered as 'babyhood' and the ages between 2 and 14 can be acknowledged as 'childhood'. The ages between 2 and 6 is 'early childhood' and the ages between 6 and 14 is 'late childhood'. A child is expected to spend its early childhood within the family. During that period they learn how to speak and share his/her ideas and emotions with the immediate family members and close environment. After the age of 1 , they become interested in colorful and shiny toys and objects. Also, they may try talking about images of objects they recognize but may not know the exact name of. For this reason, they should be presented with illustrated books written for them and be asked to interpret these images. Therefore, children will start learning more about the environment and nature as well as forming personality traits. Eventually, they will feel proud (Kıbris, 2006).

In this period, children posses the ability to understand concrete concepts and they have a rich imagination. Good quality books, which are prepared according to the developmental needs of the preschool period child, help transit from understanding concrete concepts to a more abstract level and create links between reality and imagination (Tür and Turla, 1999). 
In order to raise children who appreciate reading, books can first be introduced as a toy. At these ages, children interact with books through adults. Books with simple story lines and embellished with images are read by adults and this may form a positive basis for books as a future reference. Hence, by picking high quality books, the child may become interested in reading in the future (K1bris, 2006).

It is necessary to introduce children with books from a young age. Book should be a part of the child's life. Unfortunately, at this stage, books have to compete with colorful, and attention grabbing toys. As a result, books should be aesthetically appealing enough to divert the attention from the toys. For children with an older age, books can grab the attention with its name and topic since the child would know how to read at that stage; however, this is not the case for younger children. As a result, these ages hold a special place in children's lives. Books targeted for younger ages must have images (Alpay and Anhegger, 1975; Tür and Turla, 1999). If necessary, the images can be in color. Colored images are attractive; however, this does not mean that every child's book with colorful pictures is good. Sometimes a good black and white illustration or a simple color scheme can be more effective. The most important point here is the effective use of pictures (Oğuzkan, 1979). A good children's book should be “appealing to children's interests and in line with their mental processes, but apart from that it needs to be something that a child can read with pleasure" (Şirin, 1994).

According to Oğuzkan (1979), the preschool books should not be about children but for children. It should reflect children's mental capabilities. Books with pictures may make it easier to learn concepts and accelerates reading speed. It is important that these images should not be photographs. In general, on one hand, a child can process concrete concepts. On the other hand, they have a rich imagination. 
To help children understand content of the book, both lingual content and the imagery are important. Consequently, images play a big role. Perception means to comprehend the environment and its reactions, objects and features. In children's books, it helps to understand the content better if the pictures and text are on the same page. Especially in the books for preschoolers, this feature becomes vital (Abac1, 2003).

For Kaya (2002), images in a book are described as pictures or illustrations accompanying a text to make the meaning clearer. For children's books, the functions of images are varied. They can be used to create concepts linked to a text or it can have a meaning all by itself without an accompanying text.

In order for a child to understand human life, they need a lingual content formed by the creativity of artist. In this interaction, reader is responsible for comprehending the presented linguistic content through affective and cognitive processes. In fact, for the reader and the audience, images play a role in offering a multidimensional stimulant. It is stated that images in children's books complete, explain, and expand the meaning conveyed through texts (Sever, 2008).

\section{Necessary Basic features in Preschool books}

The design of the children's book consists of different features such as size, paper, cover, binding, page layout, font, and pictures. A book should be received well from the outside as well its insides. The effectiveness of a book's content can be measured through several criteria such as relativity of the topic, its heroes, carrying covert messages, cohesion and coherence and the correct use of Turkish language. 


\section{External features of a book}

Under the subheading below, a book's external features are listed and how they affect a child's perception and love of books (Sever, 2006:57).

\section{Sizing}

Books should be published in away that children can easily turn the pages and as a result becoming user friendly. Children between the ages of 3 and 6 likes to sort through different sized books. For them, the books should be at a size in which children can carry and hold easily in their hands. In preschool education institutions, with the recommendation from the teacher, bigger sized books can also be used (Sever, 2006:57). At this age, books are seen as a toy, children can play with these books and learn from them in a natural setting.

\section{Paper}

High quality, durable, intact, and matte papers should be used in order to press high quality images. Colors on the face of a page should not create shades on the other side of the paper. Also, the weight should not go below 90 grams. Whether a paper is matte is important since it would absorb the colors and not reflect and as a result, making it easier for a child to perceive the color and the details of the image. Though it may be high quality, shiny paper should be avoided. The surface of the paper should be smooth. This feature will help avoid tired eyes and receive colors vividly. (Tür ve Turla, 1999). The type of the paper should not be glossy paper. To turn the pages with ease, binding, glue, and stitching of the papers need to be durable and it should not fall apart (Kıbrıs, 2006).

\section{Cover - Binding}

The very first stimulant that motivates children to grab a certain is its cover. Aesthetic design of the book fosters children's ideas and imagination and hence, it would raise children's motivation to read it. A graphic designer must develop the front and the back cover of the 
book. The front cover should have an image that would represent the content of the text. (Sever, 2009:43). The front cover is as much as important as the content of the book because the preschooler does not know how to read. Good imaging and coloring techniques are important. The title of the books must be printed in such a way that it creates cohesion between the content and the title. Having an inlay of the cover will help parent select the correct book for their children in that the information regarding the writer, illustrator, the publishing house and the target age group must be clearly presented. This inlay cover must include the theme and the topic of the book. The cover must be made of sturdy materials and it must have a hard cover, which will make it user friendly (Tür and Turla, 1999). The books should be binded by forming technique. It should be stitched with a thread not a wire. These stiches should be supported with glue. Easily disseminated, seamless and paperback covers may have a negative effect on children's perception of books and building a library (Kıbris, 2006).

\section{Page layout}

All of the elements on the pages of a book (picture, photograph, texts, numbers etc.) should be in harmony with the pages' indentation, which would help reading and watching/ following the reader comfortably. Attention paid to the visual design of a page may affect children's love for books. This would also create an opportunity to help in art education (Sever, 2008:59). In the layout of the page, child must see the text and the picture referring to the text on the same page. This is especially important in audiovisual development in children. The scale and the length of a text and dimensions and number of pictures printed shows variation among ages. In the first books, the whole page could be dedicated to an illustration and the text is given a visible but a small part. Books for older children however, may have a picture covering three quarters of a page and the text may cover one quarter of a page. After the age of 7 it is recommended to go 50\% picture, 50\% text (Tür and Turla, 1999). 


\section{Font/Letters}

The letters should be legible in dimension and it should vary with the age groups. Books prepared for preschoolers should have size of 24, 22, 20 fonts. The boldness and color of the letters should appeal to the child and make it easy to read-follow the reader (Sever, 2008:62).

\section{Pictures}

In terms of design and content, the most important element of a children's book is the pictures. The reason for that is the story line of the book is completed with the help of the pictures provided. In other words, in the formation of meaning, messages conveyed with picture(s) bigger responsibility than the linguistic content provided through texts (Sever, 2006).

Children's books can be grouped under three categories. These are pictures with no text; more pictures little text and finally, few pictures longer texts. However, they cannot be without a picture (Oğuzkan, 1979). Creating a link between the story and pictures is possible through illustrations that have movement in them. Stable, photograph-like pictures may not convey the movement in the story line and therefore, are not suitable for preschoolers. These moving lines depicted through illustrations can help child retell the story (Tür and Turla, 1999).

Lines and color scheme of the pictures in the books targeted towards 2 to 3 year olds is responsible for turning concepts into visual images. In the ages of 4 and 5 pictures are visual stimulants that can be utilized with riddles, numbers, and tongue twisters, tales, stories, and poems. Pictures designed with artistic sensibility in mind aid children in perception of senses. With the aesthetic language of the visuals, children would embark on a journey of thinking and sensing. As a result, children may start trying to form a relationship between the linguistic content and the visual content (Sever, 2006:47). Pictures can transfer an abstract concept into a concrete concept. It helps children develop artistic skills (Kaplan, 2000). 
Use of round shapes without edges may make a book more attractive. Round lines can be observed in children's drawings too. Rigid and sharp lines may affect the meaning negatively. When an illustrator uses a freer technique for any other work than a child's book it is appreciated; however, it is better to work from a child's perspective when drawing. That way, it resembles more to a child's own drawing with its softness, smooth and round lines. It is advised to highlight the most important and dominant features of the story. Hence, the child would be able to understand the hero's character and its place in the story. Moreover, illustrations with color should be chosen. If the color scheme is large than the color should be chosen in a way that they would work in harmony in the composition. The colors should not overwhelm the drawing and the lines. Furthermore, the background color should also work with the drawing in harmony and it should not distract the child (Tür and Turla, 1999).

\section{The understanding of art in preschool children and the role of books}

Preschool children's understanding of art is how they approach to their own creations (Artut, 2007:33).

A research done by Hochberg and Brooks reveals that children concentrate on the pictures solely without asking for its original resource such as realia and they follow the same strategy when presented with the original realia and the pictures together. That is, they try to understand the pictures without focusing on the original (Jersild, 1978:511).

Projects involving art help children relax, and develop their creativity along with an understanding of how human mind and soul work (Artut, 2007:1). The child can be able to understand its environment better and can look at the environment from a different perspective. "In order to facilitate aesthetic point of view [in children] it is vital to include art projects with aesthetic concerns. This process longs for an active involvement of the child. So 
as to do that not only the five senses needed but also awareness is considered necessary (İlhan, 2002:11).

Though it could be a slow one, when necessary conditions are met, average children can also show growth in art and understanding of art just like their art genius peers (Milbrath, 1998:4).

In line with the development in creative thinking, children show advancements in the quality of artistic work they are creating. However, the levels of growth can vary among children. There are a number of reasons why children show variety in development. These can be summarized as education the child receives interpersonal or intrapersonal reasons (İlhan, 2009: 87).

\section{Free drawing and scrawling}

The lines from early childhood evolve into bigger and better artistic works over time and it continues to do so until adolescence. The first scrawls come to life around the age of 18 months. This scrawling phase continues until the age of 4 (Yavuzer, 2010:32). These first trials are considered as important steps in the development of art in children. These first scrawls do not posses a goal. Many psychologists accept them as games or a preparation for a next phase. Following these aimless scrawls, drawings with a goal or plan surfaces (İlhan, 2009:88). The lines turn into a head, two legs and two arms. The proportions of the body do not reflect reality. Children draw things that are important bigger than other features. Perspective is ignored. "The things that are considered as the same are drawn together or next to each other and with this techniques they learn arrangement" (Sever, 2008:48).

Around the same phase children are introduced to books. They like to look at books that have big and colorful pictures that are used to introduce simple objects. The pictures can be utilized by asking simple questions to the child. For example a picture of a cat can remind the child to the sound of cats, or a picture of a flower can help them understand the sense of smell. 
Therefore, imagination can be nourished and enriched. Colors can be taught, too (İlhan, 2000:400). They can start to understand the concept of pieces can form a whole (Sever, 2008:49).

\section{Pre-scheme period}

In terms of artistic growth, pre-scheme period covers the ages between 4 and 7. Especially around the age of 4, drawings can start to resemble things (Yavuzer,2010:41). However, at the ages of 5 and 6 , they draw their feelings and ideas. The most preferred topic is human figure. They draw a typical head to leg human body. Moreover, object nearby start to appear in their drawings. These objects are placed on the paper randomly (Vural, 2009:128) with freedom given in their drawing; they start to draw their feelings and ideas. Therefore, parents should not limit their children to draw.

Most children at the age of 5 draw purposefully. The heads they scrawl are usually big. With age, they advance in holding a pen. This development affects their drawings. With the age of 6, children start to draw more realistically. For example, women can be represented with long hair, wearing a dress and with makeup. The figure of men would have short hair and mustache and wearing pants. The places they draw would reveal more details too. Unlike the figure placed randomly somewhere on paper, they start to focus on a place and even draw a line to represent the ground and place figures on top of it. New features of the human body is added such as fingers, neck, pupils and ears. The face with one dimension, start to possess elements from a second dimension. Also, the proportions of certain body parts show differences. For instance, a child at the age of 5 draws a bigger head compared to an older child. (İlhan, 2009: 91; Yavuzer, 2010: 42).

During this pre-scheme period, the child can easily use pen, scissors and brushes. They are attracted to shiny and colorful art tools. They enjoy using pens and brushes with colorful 
paints on big papers. They are free and brave with their colors. It can be observed that instead of the real color of an object, they may use their favorite color to paint it. They enjoy coloring. Their paint strokes usually follow a pattern from up to bottom or left to right (Artut,2007:46). During this period they paint freely. They do not feel the need to consult someone (Buyurgan, 2012:51) With the event of a negative comment on their drawings or paintings, they may refrain from drawing or painting in the future, so it is vital not to interfere or guide them.

\section{The role of books in the development of art in children}

Another great contribution to the growth of art in children is the existence of books. Books are the most effective tools in teaching aesthetics. Art historians and educators studied children's art. These scholars claim that these books are effective tools (Roll, 1988:511). A high quality children's book support the development of art and they are usually the first tools that have art in them. For this reason, the quality of the pictures included in these books carry an important role. Books with pictures should support children's growth (Çılgın, 2007).

Unlike common knowledge, children start to associate the pictures in the books with the objects around them much sooner. It starts around 11 months (Aslier, 1975:20). The first encounter with books is usually the books with pictures. They start with books with only pictures and move on to books with pictures and phrases or texts. During this transition phase, if the child were given high quality books with pictures, their chances of going forward with books would multiply (Kartal, 2004:47).

The relationship found between the child and the book is affected by how good an illustrator understands the world of children and draws it effectively. To pass the habit of conveying messages through pictures in children, it is and important step to choose books with high quality, well thought illustrations. These pictures help give meanings of abstract concepts that may be expressed effectively through words. Moreover, it helps expand imagination in 
children. As a consequence, there is a need for the existence of creative work that would ignite all of these things (Ergen, 2009:9).

By studying the pictures in detail, forming meaning, and using imagination at the same time is a feature of this period. Children between the ages of 2 and 5 are closer to books. At the age of 3, they can find a cause effect relationship between pictures. The books prepared for these ages must ignite their imagination (İlhan, 2000:401). It is highly unlikely to think about books for children that do not have pictures in them. These books with pictures aid in understanding the plot and nourish imagination and aesthetic values (Roll, 1987:512).

The main objective of having pictures in books is to advance children's visual perception. Consequently, the pictures must be in parallel with the age of the child. Experts must be employed in the development and selection of pictures. The illustration should not just tell the story in the book. It should also be concerned about feeding the imagination. These images can be seen as a support to perception, imagination, dreaming, collecting information and entertainment. Along with these, it should encourage children to draw and paint (İlhan, 2000:402). Awakening desire to draw in children may unfold a positive relationship between the child and the illustrator. Therefore, lines and colors depicted in the illustrations should be paid close attention to and the figures whether animate or inanimate must be depicted in a simplified manner (Sever, 2008:169).

Children at the age of 4 can evaluate past, present and future. They can also inquire about why, when and how. They can listen to long stories. Real life and dreams or imaginative reflections can be mixed up. As a result, books aimed at these ages should include details but at the same time it should also have surrealistic elements (İlhan, 2000:401).

Books designed for children at the age of 5 should include illustrations about both concrete concepts and abstract concepts. Abstract illustrations may help in terms of the expansion of 
imagination. The illustrations should follow the developmental stages of this age (İlhan, 2000:401).

Children at the age of 6 show quite a lot of variations when compared to other ages. First and foremost, they are more realistic. They compare the illustrations depicted and the story told in the book. They read and form images based on their readings, which is not the case in the younger ages. After the age of 6, pictures, images and illustrations get lower in numbers but the details of the images would have a higher importance (İlhan, 2000:402).

Illustrations simplify the meaning conveyed through the texts in the books. It forms a shortcut to the path between topic and plot. This shortcut help reach a ready made knowledge and take a step further by reflecting emotions. Moreover, these pictures can depict meaning that may be missed when reading. Hence, the presentation of images becomes an important factor. Furthermore, it works as a break from reading words to the child. Although there may not be a need to garnish the text with illustrations, this is usually the result of having images (Shulevitz, 1997:120).

\section{Illustrated Fairy Tale Books Researched of Preschool Children's}

\section{Small Purple Fish}

Small Purple Fish perform multiple functions at the same time is a composition. Çınaroğlu's (1998) Small Purple Fish pictures in the short story, the child can draw and cut the like can be implemented easily by imitating properties. The child; both colors and numbers, and basic forms in nature, square, triangle, circle shape is introduced. Different ones, and even the fact that they have something in common with differences could be together in harmony, there is Perceiving. Children's cognitive development possibilities for creating geometric colorful photos, without the support of a linguistic expression constitute a visual text in the book. 
Ayla Çınaroğlu formed the heroes of the story by colorizing papers, wrinkling, ironing, and then cut and cuting. She has explained to the kids to how can they do them on the back page of the book. These explanations are given in order to be able to do with their parents, teachers. Author with this work inspired to the children, creativity is not limited to with squares or triangles.

Artwork children's listening, speaking, reading and writing skills can help developing. It can help to gain children's language awareness and sensitivity. Developing skills of children dreamingascend to fantastic adventure keep them. It can create the opportunity to children playing, laughing, and having fun. It can contribute to children's hands muscle development and motor skills.

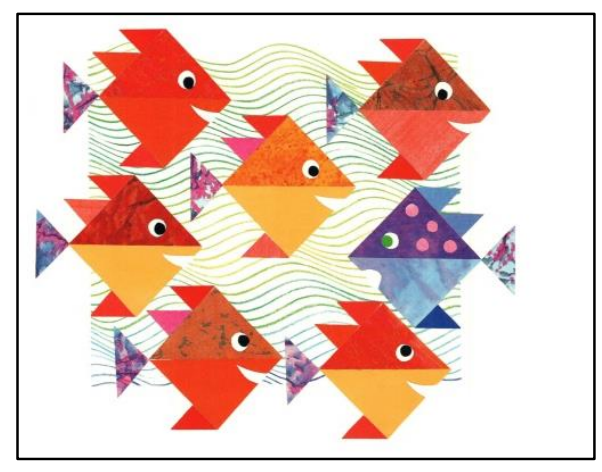

(Çınaroğlu, 1998:7)

When we look at the book in terms of structure; the design features (size, cover-skin, paper, page layout, letters, pictures) structure that's called age group (3-5 years old) are seen to have the appropriate qualifications. Artwork contained in files, along with the text verbal meaning of events to occur, and may contribute to stimulate the little readers' memory.

\section{I'm a Line}

Öğmel (2010)'s in story “I'm a Line”, the hero is a line. Artwork present to the children the color of the line offering all the narrative possibilities of the visual identity introduces many 
objects. In the book of the moving objects created through the lines and organisms are presented in a manner appropriate to the child's world.This book used to in the early stages pre-school and elementary school children's created using the original lines of children and writing characters are drawn into the story together with them. There is the reality of their own lives and in finding objects similar to those that exist around is to see.This can helped to create images of objects and assets contribute to the development of the concept in memory of the children.These objects are created with very simple lines and picture. The children imitating their simplicity and quality. Pictures of children in the visual arrangement can be improve visual perception and children painting can be said that the request wake.

"I'm a Line" work, created with the hero child's development environment by creating a painting course in accordance with specifications educational - feel was able to be trainers (Sever, 2008:88).

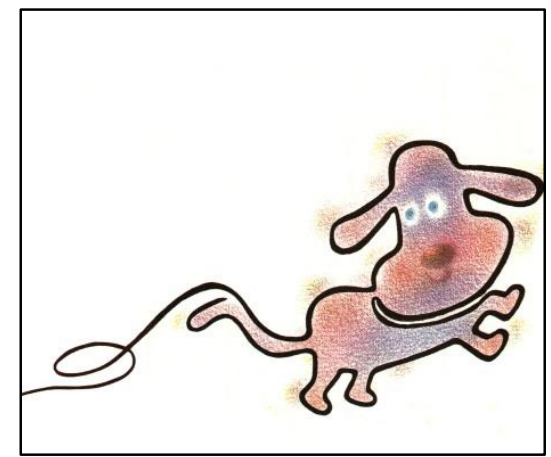

(Ö̈̆mel, 2010: 9)

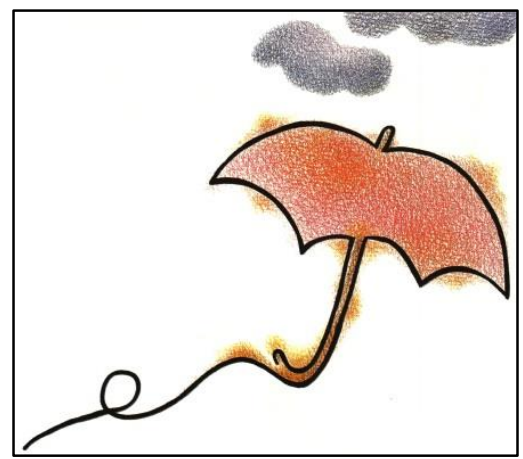

(Ö̈̆mel, 2010: 27)

\section{Journey}

"Journey" is a work of children's literature who is a Seza Kutlar Aksoy imparted to children's literature for pre-school children and Serap Deliorman is an illustrator of this book.

The pictures used for two thirds of which covers all this book. The format of the lines is unique. The effect of the lines have special property that are interested in by the 
children.Pictures is completed the verbal meaning of the text .Pictures can helped to words to describe in the child's memory contribute to stimulus.Pictures was able to commented to visual text.Books can awaken a desire to make pictures in children. It can feed their imagination. Artwork can contribute to children's linguistic, cognitive, personality and social development. As an example of the our story 16 and 22 in the pages, but the real child is made similar to a child's drawing files are located. When we look at the these images and pictures located in other pages of the book, we look at the general structure of reality in the child take their places according to the pictures to make his readers of the artwork can be said that.

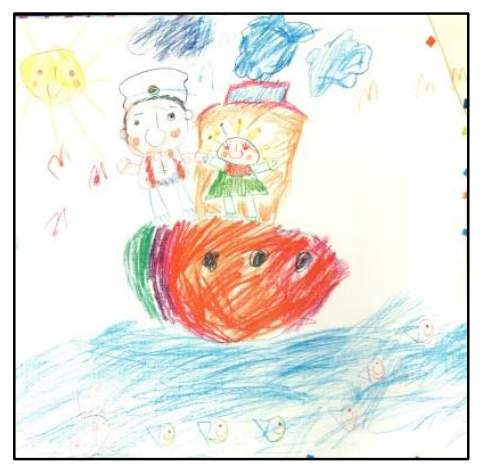

(Aksoy, 2009:16)

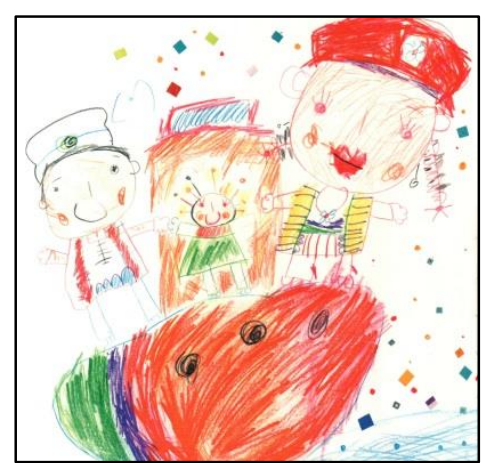

(Aksoy, 2009:22)

\section{Birthday Gifts}

Behiç Ak's Birthday Gifts book is oversized and children communication is established with only the artistic quality pictures. Book features in the stories of children will develop visual perception by showing the lines and colors are created. On the book cover, in shades of blue and green a framework which depicted a big gift package in hand within little boy friendly.Cover design located in the lower right corner of the green color cute cat, the child will lead to the book to create a visual impact.Pictures in books; from part to whole, is followed by a sequence that goes from abstract to concrete. The audience on the first page of the book with a night indigo blue, almost covering his later encounters a vague picture of the sea.Precisely at the point where the sea and sky merged, noticed a small stain in green.In the following pages, this small stain on the horizon, gradually approximated the reader.On the 
first page of the invention where the sea and sky green stain that appears, increasingly in later pages of the book with the formal characteristics begin to appear.Firstly red boat which is depicted in front of a green island.Green and red windows on the next page charming white houses, trees, birds, and many island image with sandal is drawn.Book artist, as previously discussed forms of holistic in more detail on other pages of photos; Birds flying above the trees, a stone attached to the edge of the shore boat, which hung on the roof of the house such as washing clothes.In the following pages the following (readers), are directed into a house on the island; audience (reads) the cover of the book with a picture of this time, a history meets the re-forming elements; After a birthday gift in the hands of the hero (child) is brought together with and cute cat.Stories, gift package of joy from the stairs and out of the house (street) of the dash where the hero and cute cat visual arrangements are maintained. These regulations, that increase children's sense of wonder in a game of fiction, gift package inside another package with the release of a smaller continues (Sever, 2008:11).

Child opening a gift pack of friends around, with curious eyes and look at the combo packages are eagerly repeatedly. The last package inside a tiny box in green color and an egg out of him too. Children and cat suddenly cracked egg in amazement staring at the inside of the egg in orange cute, tiny fledgling interests. Facial expressions in the pictures of the heroes, people who reflect the different moods successfully. In the book, the story of the creation of images with expressive language; children by asking, thinking, has the characteristics of a puzzle image can participate amused. Opportunities created through color and line, children's dreams and thoughts to mobilize the power of this visual puzzle; them, under the guidance of color pictures that might interest are the various feelings and thoughts adventure (Sever, 2008:12). 
This book do not have any written text and then in all of the pictures, readers have created their own stories through pictures. We can say that with this pictures, little book readers can add many different images in their images world.

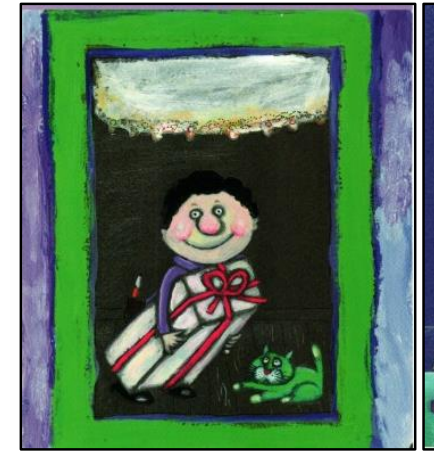

$(A k, 2012: 13)$

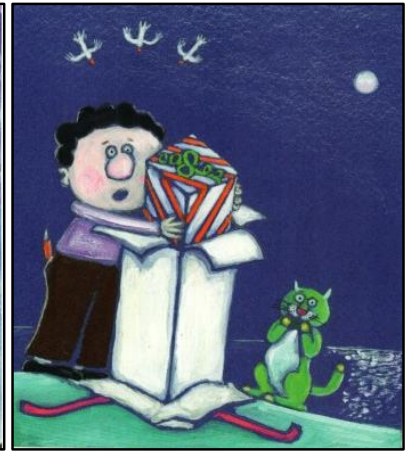

$(A k, 2012: 17)$

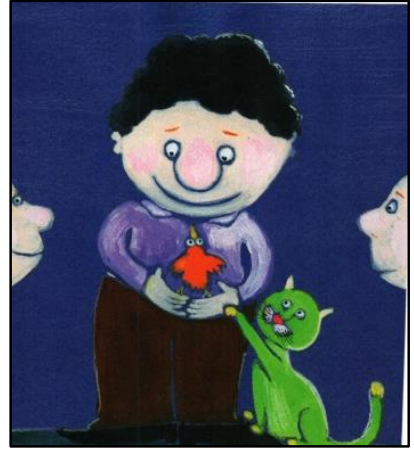

$(A k, 2012: 28)$

\section{Result}

Pre-school period illustrated children's tales that appeal to children's linguistic, cognitive, personality and social development plays an important role in terms of phases. Designed in a manner appropriate to the reality of children's and illustrated fairy tales, children's both visual and linguistic, cognitive, personality and social development provides a major contribution to the stage. Children according to their own reality imitating fable, pictures, along with images of their dream world begin to take the first step into art education. Accurate and wellillustrated fairy tale pictures, as a stimulus to children's hearing, thinking, dreaming serves responsibility. Child can be started to first step in arts education with the pictures which illustrated in the book is simple, plain, prepared with sensitivity artists.

Pre-school period illustrated children's tales for children's art education is important. We can start with children in a natural learning environment to provide arts education. It can begin with a book which is written and illustrated an artist for children's tale with a sensitivity for who is a 2 years old and up. Children to engage in misleading suggestions for the development of children's art education holds an important place. The necessary environment 
can contribute to arts education to without interfering with their imagination and drawing, without dulling their creativity, without limiting them only by promoting by preparing materials.

\section{References}

Abacı, O. (2003). Okul Öncesi Eğitim Kurumlarında Görsel Sanat Eğitimi. (Ed.: Müzeyyen Sevinç), Erken Çocuklukta Gelişim ve Eğİtimde Yeni Yaklaşımlar, İstanbul: Morpa Kültür Yayınları.

Ak, B. (2012). Doğum Günü Hediyesi, Üçüncü Basım, İstanbul: Can Çocuk Sanat Yayınları.

Aksoy, S. K. (2009). Yolculuk, Birinci Basım, İzmir: Tudem.

Artut, K. (2007). Okul Öncesinde Resim Eğitimi. İkinci Baskı, Ankara: Anı Yayıncılık.

Aslıer M. (2009). Çocuk Kitaplarının Grafik Tasarımı, İlköğretmen Eğitimci Dergisi, 6-9.

Aşılıoğlu, E. (2011). Grafik Sanatçılarının Çocuk Kitaplarının Grafik Tasarımına İlişkin Görüşlerinin Değerlendirilmesi, Yayımlanmamış Yüksek Lisans Tezi, Ankara Üniversitesi Eğitim Bilimleri Enstitüsü.

Binbaşığlu, C. (1995). Okullarda Öğretim Sorunları. Ankara: Eğit-Der Yayınları, 5.

Buyurgan, S. ve Buyurgan, U. (2012). Sanat Eğitimi ve Öğretimi Eğitimin Her Kademesine Yönelik Yöntem ve Tekniklerle, Geliştirilmiş Üçüncü Baskı, Ankara: Pegem Akademi.

Çılgın, A. S. (2007). Çocuk Edebiyatı, İstanbul: Morpa Kültür Yayınları Ltd.

Çınaroğlu, A. (1998). Küçük Mor Balık, Üçüncü Baskı, İzmir: Uçanbalık Yayıncılık. 
Dursun, Ö. (2008). Okulöncesi Eğitimde Materyal Geliştirme Süreci ve İlkeleri, (Ed. S. Duygu Erişti) “Okulöncesinde Materyal Geliştirme ve Görsel Sanatlar Eğitimi” içinde, (ss.1-26), Eskişehir: Anadolu Üniversitesi Yayını, No: 1845.

Ergen, E. (2009). Kavramların Algılatılmasında Resimli Çocuk Kitaplarının Rolü Bağlamında “Simyacının Hediyesi” Öyküsü İçin Çocuk Kitabı Tasarımı, Yayımlanmamış Sanatta Yeterlilik Tezi, Hacettepe Üniversitesi, Sosyal Bilimler Enstitüsü

Güleç, H. Ç. (2008). Okulöncesi Eğitime Giriş. Okulöncesi Eğitimin Temel İlkeleri. (Ed: G, Haktanır). Ankara: Anı Yayıncılık.

İlhan, A. Ç. (2000). Çocuk Kitaplarının Sanat Eğitimi Açısından Değerlendirilmesi. I. Ulusal Çocuk Kitapları Sempozyumu, Ankara: AÜEBF ve TÖMER Dil Öğretim Merkezi Yayınları, 399-403.

İlhan, A. Ç. (2002). “Okulöncesi Dönemde Estetik Duyarlılı̆̆ın Geliştirilmesi”, Öğretmen Dünyası, Ankara, 270, 16-20.

İlhan, A. Ç. (2003). "Okulöncesi, Yaratıcılık ve Sanat Eğitimi”" Okulöncesi Eğitimde Yaratıcılık ve Drama, (Edt: Ali Öztürk) “Açıköğretim Fakültesi Okulöncesi Öğretmenliği Lisans Programı, Anadolu Üniversitesi Yayınları.1488, 105-118.

Jersild, A. T. (1979) Çocuk Psikolojisi, Çev: Gülseren Günce, Ankara Üniversitesi Eğitim Fakültesi Yayınları, No: 79. Ankara.

Kartal, N. (2004) Resimli Çocuk Kitaplarında Canavar İmgesi, Yayımlanmamış Yüksek Lisans Tezi, Hacettepe Üniversitesi Sosyal Bilimler Enstitüsü.

Kıbrıs, İ. (2006). Çocuk Edebiyatı. Ankara: Özkan Matbaacılık. 
Kutlu, S. (2011). “ Okulöncesi Çocuk Edebiyatı Yapıtlarındaki Resimlerin Çocuğa Göreliğinin Öğretmen Görüşlerine Göre Değerlendirilmesi (Eskişehir İli Örneği), Yayımlanmamış Yüksek Lisans Tezi, Ankara Üniversitesi Eğitim Bilimleri Enstitüsü.

Milbrath, C. (1998). Patterns of Artistic Development in Children: Comparative Studies of Talent, Cambridge University Pres.

Oğuzkan, F. (1979). Yerli ve Yabancı Yazarlardan Örneklerle Çocuk Edebiyatı. Ankara: Kadığlu Matbaası.

Öğmel, Ümit. (2010). Ben Bir Çizgiyim, Altıncı Baskı, Ankara: Kök Yayıncılık.

Özer, A. (2007). “Çocuk Kitaplarındaki Resimlemelerin Çocuğa Göreliği”. II. Ulusal Çocuk ve Gençlik Edebiyatı Sempozyumu. (Gelişmeler, Sorunlar ve Çözüm Önerileri). (Yay. Haz.: S. Sever) Ankara Üniversitesi Eğitim Bilimleri Fakültesi Yayını, No: 203, 425 432.

Roll, D. (1987). Çocuk Kitaplarını Resimleme Sanatı, (Çev: Banu Yalçın) Çocuk Edebiyatı Y1llı̆̆1, İstanbul: Gökyüzü Yayınları 511-514.

Sever, S. (2008). Okulöncesinde Çocuk Edebiyatı. (1.Baskı). (Ed: Güneş, Z.) Eskişehir: Anadolu Üniversitesi Açık Öğretim Fakültesi Yayınları.

Sever, S. (2008). Çocuk ve Edebiyat. İzmir: Tudem Yayınları.

Sever, S. (2009). İlköğretimde Çocuk Edebiyatı. (2.Baskı). (Ed: Güneş, Z.) Eskişehir: Anadolu Üniversitesi Açık Öğretim Fakültesi Yayınları.

Sever, S. (2013). Çocuk Edebiyatı ve Okuma Kültürü. (1. Basım). İzmir: Tudem Yayınları.

Shulevitz, U, (1997). Writing With Pictures: How to Write and Illustrate Children's Boks, New York: Watson-Guptill Puliciations. 
Şirin, M. R. (1994). 99 Soruda Çocuk Edebiyatı, İstanbul: Çocuk Vakfı Yayınları.

Tür, G. ve Turla, A. (1999). Okulöncesinde Çocuk Edebiyat ve Kitap, İstanbul: Ya-Pa Yayınlar1.

Vural, D. Ü. (2009). Çocuğun Sanatsal (Grafiksel) Gelişim Basamakları, Sanat Eğitimi ve Görsel Sanatlar Öğretimi, Ankara: Pegem Akademi Yayınevi. 125-148.

Yavuzer, H. (2010). Resimleriyle Çocuk: Resimleriyle Çocuğu Tanıma, Ondördüncü Basım, İstanbul: Remzi Kitabevi.

Zembat, R. ve Unutkan, P. (2001). Okulöncesi Dönemde Çocuğun Sosyalleşmesinde Ailenin Yeri. İstanbul: Ya-Pa Yayınları. 